\title{
Response
}

\section{Acute Hyperglycemic Crises with Coronavirus Disease-19: Case Reports (Diabetes Metab J 2020;44: 349-53)}

\author{
Na-young $\mathrm{Kim}^{1, \star}$, Eunyeong $\mathrm{Ha}^{2, \star}$, Jun Sung Moon ${ }^{2}$, Yong-Hoon Lee ${ }^{3}$, Eun Young Choi ${ }^{2}$ \\ ${ }^{1}$ Division of Endocrinology and Metabolism, Department of Internal Medicine, Kyungpook National University Hospital, School of Medicine, Kyungpook \\ National University, Daegu, \\ ${ }^{2}$ Department of Internal Medicine, Yeungnam University College of Medicine, Daegu, \\ ${ }^{3}$ Division of Pulmonary and Critical Care Medicine, Department of Internal Medicine, Kyungpook National University Hospital, School of Medicine, \\ Kyungpook National University, Daegu, Korea
}

We would like to thank Professor Ja Young Jeon for their interest in and comments regarding our case report, entitled "Acute hyperglycemic crises with coronavirus disease-19: case reports" which was published in Diabetes \& Metabolism Journal [1].

We agree with Professor Jeon's opinion that diabetes is closely related to poor outcomes, treatment responsiveness, and serious acute diabetic complications in severe coronavirus disease-2019 (COVID-19).

First, we will briefly describe the progress of the second patient, who showed hyperglycemic hyperosmolar state (HHS) along with COVID-19, since our case report was published. Unfortunately, the patient's fever relapsed with a re-positive result on COVID-19 polymerase chain reaction (PCR) test on the 47th hospital day. At that time, this was thought to indicate re-infection requiring quarantine, but according to a recent announcement by the Korean Centers for Disease Control and Prevention, this situation was caused by the limitations of PCR testing, actual activity of coronavirus is unknown. For COVID-19 diagnosis using PCR, genetic material of the virus is amplified and it is possible to detect both live virus and fragments of dead virus that can take months to clear from recov- ered patients. Based on this knowledge, the result of re-positivity on PCR test is considered false-positive but not active infectivity [2]. The patient was treated with antibiotics (carbapenem) for 7 days and her fever subsided. In addition, the mechanical ventilator was removed on the 61st hospital day. She was moved from the intensive care unit to the general ward on the 71st hospital day.

Regarding the first case, as mentioned in the article, the patient halted antidiabetic medications a few months ago and was taking only calcium channel blockers as an antihypertensive drug.

In the second case, the patient took metformin and glimepiride as oral hypoglycemic agents but were not taking medications for hypertension and dyslipidemia, which had previously been diagnosed by a doctor. When the patient was admitted, initial blood pressure and heart rate were $114 / 72 \mathrm{~mm} \mathrm{Hg}$, and 71 beats/min, respectively. Lipid profile was also within normal range (total cholesterol $126 \mathrm{mg} / \mathrm{dL}$, high-density lipoprotein cholesterol $50.1 \mathrm{mg} / \mathrm{dL}$, triglyceride $158 \mathrm{mg} / \mathrm{dL}$, and low-density lipoprotein cholesterol $44.3 \mathrm{mg} / \mathrm{dL}$ ). Continuous intravenous insulin injection was initiated immediately for treatment of HHS and switched to subcutaneous injections after stabili-
Corresponding authors: Yong-Hoon Lee (D https://orcid.org/0000-0001-5972-2866 Division of Pulmonary and Critical Care Medicine, Department of Internal Medicine, Kyungpook National University Hospital, School of Medicine, Kyungpook National University, 130 Dongdeok-ro, Jung-gu, Daegu 41944, Korea E-mail: id0121@naver.com

Eun Young Choi (iD https://orcid.org/0000-0003-2974-5447

Department of Internal Medicine, Yeungnam University College of Medicine, 170

Hyeonchung-ro, Nam-gu, Daegu 42415, Korea

E-mail: letact@yu.ac.kr

*Na-Young Kim and Eunyeong Ha contributed equally to this response as first authors.
This is an Open Access article distributed under the terms of the Creative Commons Attribution Non-Commercial License (https://creativecommons.org/licenses/by-nc/4.0/) which permits unrestricted non-commercial use, distribution, and reproduction in any medium, provided the original work is properly cited. 
zation. Interestingly, this patient showed high blood pressure after moving to the general ward so she was prescribed antihypertensive medications (losartan, bisoprolol, furosemide, and spironolactone).

Angiotensin-converting enzyme 2 (ACE2) acts as a cellular receptor for severe acute respiratory syndrome coronavirus (SARS-CoV) and severe acute respiratory syndrome coronavirus 2 (SARS-CoV2) [3]. There is some evidence that the use of drugs that increase ACE2 expression, such as renin-angiotensin system (RAS) inhibitors and thiazolidinediones, may accelerate the development of COVID-19 [4]. In addition, glucagon-like peptide-1 receptor agonist [5] and statin [6] can upregulate ACE2. However, insulin administration attenuates ACE2 expression [7]. In recent studies [8,9], RAS inhibitors did not exacerbate the course of COVID-19, so the medications mentioned by Professor Jeon did not have a significant effect of COVID-19 severity. We suggest that patients do not need to stop taking these medications.

Thank you again for your interest in our research and for your thoughtful comments.

\section{CONFLICTS OF INTEREST}

No potential conflict of interest relevant to this article was reported.

\section{REFERENCES}

1. Kim NY, Ha E, Moon JS, Lee YH, Choi EY. Acute hyperglycemic crises with coronavirus disease-19: case reports. Diabetes Metab J 2020;44:349-53.

2. Ministry of Health and Welfare: Coronavirus disease-19, Republic of Korea, Updates on COVID-19 in Republic of Korea (as of 18 May). Available from: http://ncov.mohw.go.kr/tcmBoardView.do?brdId $=\&$ brdGubun $=\&$ dataGubun $=\& n c v C o$
ntSeq=354596\&contSeq=354596\&board_id=140\&gubun= BDJ (cited 2020 Jun 8).

3. Li W, Moore MJ, Vasilieva N, Sui J, Wong SK, Berne MA, Somasundaran M, Sullivan JL, Luzuriaga K, Greenough TC, Choe H, Farzan M. Angiotensin-converting enzyme 2 is a functional receptor for the SARS coronavirus. Nature 2003; 426:450-4.

4. Fang L, Karakiulakis G, Roth M. Are patients with hypertension and diabetes mellitus at increased risk for COVID-19 infection? Lancet Respir Med 2020;8:e21.

5. Romani-Perez M, Outeirino-Iglesias V, Moya CM, Santisteban P, Gonzalez-Matias LC, Vigo E, Mallo F. Activation of the GLP1 receptor by liraglutide increases ACE2 expression, reversing right ventricle hypertrophy, and improving the production of SP-A and SP-B in the lungs of type 1 diabetes rats. Endocrinology 2015;156:3559-69.

6. Tikoo K, Patel G, Kumar S, Karpe PA, Sanghavi M, Malek V, Srinivasan K. Tissue specific up regulation of ACE2 in rabbit model of atherosclerosis by atorvastatin: role of epigenetic histone modifications. Biochem Pharmacol 2015;93:343-51.

7. Riera M, Marquez E, Clotet S, Gimeno J, Roca-Ho H, Lloreta J, Juanpere N, Batlle D, Pascual J, Soler MJ. Effect of insulin on ACE2 activity and kidney function in the non-obese diabetic mouse. PLoS One 2014;9:e84683.

8. Chung SM, Lee YY, Ha E, Yoon JS, Won KC, Lee HW, Hur J, Hong KS, Jang JG, Jin HJ, Choi EY, Shin KC, Chung JH, Lee $\mathrm{KH}, \mathrm{Ahn} \mathrm{JH}$, Moon JS. The risk of diabetes on clinical outcomes in patients with coronavirus disease 2019: a retrospective cohort study. Diabetes Metab J 2020;44:405-13.

9. Jung SY, Choi JC, You SH, Kim WY. Association of renin-angiotensin-aldosterone system inhibitors with COVID-19-related outcomes in Korea: a nationwide population-based cohort study. Clin Infect Dis 2020 May 22 [Epub]. https://doi. org/10.1093/cid/ciaa624. 